\title{
OTORITAS J ASA KEUANGAN: SISTEM BARU DALAM PENGATURAN DAN PENGAWASAN SEKTOR J ASA KEUANGAN
}

\author{
Hesty D. Lestari \\ Magister IImu Hukum, Uiversitas Muhammadiyah J akarta \\ E-mail: hesty.lestari@gmail.com
}

\begin{abstract}
A new institution has been created by Act Number 21 of 2011 regarding the Financial Services Authority (Otoritas J asa Keuangan/OJ K). The new institution, also named OJ K, has the function of conducting an integrated regulatory and supervisory sistem for the whole activities in the financial services industry. It takes over the function of the Bank of Indonesia in banking supervision and the function of the Capital Market and Financial Institution Supervisory Agency in supervising capital market, insurance, pension fund, and other financial services. OJ $\mathrm{K}$ is responsible for maintaining the stability of the Indonesian financial system.
\end{abstract}

Key words: FSA, financial system, banking supervision

\begin{abstract}
Abstrak
Sebuah lembaga baru telah dilahirkan oleh UU Nomor 21 Tahun 2011 tentang Otoritas J asa Keuangan (OJ K). Lembaga baru tersebut, yang juga dinamai OJ K, memiliki fungsi untuk menyelenggarakan sistem pengaturan dan pengawasan yang terintegrasi terhadap keseluruhan kegiatan di dalam sektor jasa keuangan. OJ K mengambil alih fungsi dari Bank Indonesia dalam pengawasan perbankan dan fungsi Bapepam-LK dalam pengawasan pasar modal, asuransi, dana pensiun, serta jasa keuangan lainnya. OJ K bertanggung jawab untuk menjaga stabilitas sistem keuangan Indonesia.
\end{abstract}

Kata kunci: OJ K, sistem keuangan, pengawasan perbankan

\section{Pendahuluan}

Disahkannya UU No. 21 Tahun 2011 tentang Otoritas J asa Keuangan, maka sistem baru dalam pengaturan dan pengawasan sektor jasa keuangan di Indonesia telah dimulai. UU tersebut melahirkan lembaga baru yaitu Otoritas Jasa Keuangan (selanjutnya disebut OJ K), yang harus sudah terbentuk paling lambat tanggal 22 Juli 2012. OJ K adalah lembaga yang independen dan bebas dari campur tangan pihak lain, yang memiliki fungsi untuk menyelenggarakan sistem pengaturan dan pengawasan yang terintegrasi terhadap keseluruhan kegiatan pada sektor jasa keuangan.

Selama ini, pengaturan dan pengawasan sektor jasa keuangan di Indonesia dilakukan oleh dua lembaga, yaitu Bank Indonesia (BI) dan Badan Pengawas Pasar Modal-Lembaga Keuangan (Bapepam-LK). BI mengatur dan mengawasi sektor Perbankan, sedangkan Bapepam-LK mengatur dan mengawasi sektor Pasar Modal dan sektor Perasuransian, Dana Pensiun, Lembaga Pembiayaan dan Lembaga J asa Keuangan lainnya. Pembentukan OJ K ini mengakibatkan kewenangan-kewenangan tersebut beralih dari BI dan Bapepam-LK ke OJ K, sehingga BI hanya memiliki kewenangan di bidang kebijakan moneter saja, sedangkan Bapepam-LK lebur menjadi OJ $\mathrm{K}$ dan tidak lagi di bawah Kementerian Keuangan.

Ide melepaskan fungsi pengawasan perbankan dari BI sudah muncul pada masa pemerintahan Presiden B.J . Habibie, ketika Pemerintah menyusun RUU tentang BI (yang kemudian menjadi UU No. 23 Tahun 1999). ${ }^{1}$ Krisis keuangan yang melanda Indonesia pada masa itu menunjukkan adanya kelemahan dalam sistem pengawasan perbankan oleh bank sentral. Pemerintah dan DPR kemudian menyepakati untuk

Zulkarnain Sitompul, "Menyambut Kehadiran Otoritas Jasa Keuangan", Pilars, 12-18 Januari 2004, No. 2 Tahun VII, hlm. 1. 
memisahkan kewenangan kebijakan perbankan makro dan mikro, di mana bank sentral menangani perbankan makro, sedangkan perbankan mikro diserahkan pada suatu lembaga pengawas jasa keuangan (LPJ K). ${ }^{2}$ Ketentuan Pasal 34 UU No. 23 Tahun 1999 tentang BI mengatur bahwa tugas menga-wasi bank akan dilakukan oleh LPJ K yang independen dan dibentuk dengan UU, di mana pembentukan LPJ $\mathrm{K}$ tersebut dilaksanakan selambat-lambatnya akhir Desember 2002.

Belum lagi LPJ K terbentuk, Pemerintah mengajukan RUU Perubahan UU tentang BI, yang setelah disetujui oleh DPR menjadi UU No. 3 Tahun 2004. Berdasarkan UU tersebut, LPJ K (yang kemudian disebut OJ K) dibentuk paling lambat tahun 2010. Namun target waktu ini pun tidak dapat dipenuhi karena alotnya pembahasan RUU tentang OJ K antara Pemerintah (diwakili Kementerian Keuangan), BI dan DPR. RUU OJ $\mathrm{K}$ akhirnya disetujui oleh DPR pada tanggal 27 Oktober 2011 dan kemudian menjadi UU No. 21 Tahun 2011.

Sejumlah harapan digantungkan kepada lembaga yang baru terbentuk ini. OJ $\mathrm{K}$ diharapkan dapat menjaga stabilitas sistem keuangan untuk pencegahan dan penanganan krisis keuangan, sehingga krisis keuangan seperti yang terjadi pada akhir tahun 1990an tidak akan terjadi lagi. OJ K juga diharapkan dapat meminimalisir tindak kejahatan di sistem dan lembaga keuangan yang diprediksi akan terus terjadi dengan mekanisme yang semakin canggih dan mutakhir, sehingga kasus-kasus seperti Bank Century dan sekuritas Antaboga serta penggelapan dana nasabah Citibank tidak akan terjadi lagi. OJ K, sebagai lembaga independen, diharapkan tidak akan menjadi kepanjangan tangan pemerintah, partai politik yang tengah berkuasa, atau pun pihak-pihak lain yang berkepentingan.

Permasalahan yang akan dibahas dalam artikel ini mencakup 3 hal. Pertama, bagaimanakah pengaturan lembaga OJ $\mathrm{K}$ berdasarkan UU No. 21 Tahun 2011? Kedua, bagaimanakah pelaksanaan lembaga sejenis $0 \mathrm{~J} \mathrm{~K}$ di Inggris dan

Andika Hendra Mustaqim, "Otoritas Jasa Keuangan Sebagai Solusi Sistem Ekonomi Nasional", Perspektif, Vol. 8, No. 1 Tahun 2010, hlm. 6. di J epang? Ketiga, apakah OJ K akan ber-fungsi lebih baik dibandingkan dengan BI dan Bapepam-LK dalam hal pencegahan dan penanganan krisis keuangan, independensinya, dan pemberian perlindungan konsumen di sektor jasa keuangan?

\section{Pembahasan}

\section{OJ K Berdasarkan UU No. 21 Tahun 2011}

Pembentukan OJ K bertujuan agar keseluruhan kegiatan dalam sektor jasa keuangan terselenggara secara teratur, adil, transparan dan akuntabel, serta mampu mewujudkan sistem keuangan yang tumbuh secara berkelanjutan dan stabil. Hal yang tidak kalah penting adalah agar seluruh kegiatan di sektor jasa keuangan mampu melindungi kepentingan Konsumen dan masyarakat.

Tugas OJ $\mathrm{K}$ adalah mengatur dan mengawasi 3 sektor jasa keuangan, yaitu sektor Perbankan, sektor Pasar Modal, serta sektor Perasuransian, Dana Pensiun, Lembaga Pembiayaan dan Lembaga J asa Keuangan lainnya. Khusus di sektor Perbankan, OJ K memiliki kewenangan untuk mengatur dan mengawasi kelembagaan bank, kesehatan bank dan aspek kehati-hatian bank, serta untuk melakukan pemeriksaan bank. Dengan demikian, masalah perizinan untuk pendirian bank, serta pencabutan izin usaha bank menjadi kewenangan OJ $\mathrm{K}$.

OJ $\mathrm{K}$ berwenang untuk melakukan pengawasan, pemeriksaan, penyidikan, perlindungan Konsumen dan tindakan lain terhadap Lembaga J asa Keuangan, pelaku, dan/atau penunjang kegiatan jasa keuangan sebagaimana dimaksud dalam peraturan perundang-undangan di sektor jasa keuangan terhadap ketiga sektor jasa keuangan tersebut. OJ $\mathrm{K}$ juga berwenang menetapkan sanksi administratif terhadap pihak yang melakukan pelanggaran terhadap peraturan perundang-undangan di sektor jasa keuangan. Kewenangan lain dari OJ K adalah memberikan dan/ atau mencabut izin usaha, izin orang perseorangan, efektifnya pernyataan pendaftaran, surat tanda terdaftar, persetujuan melakukan kegiatan usaha, pengesahan, persetujuan atau penetapan pembubaran dan penetapan lain se- 
bagaimana dimaksud dalam peraturan perundang-undangan di sektor jasa keuangan.

Berdasarkan ketentuan Pasal 10 ayat (4) UU OJ K, OJ K dipimpin oleh Dewan Komisioner yang terdiri dari 9 orang anggota yang bersifat kolektif dan kolegial. Susunan Dewan Komisioner adalah sebagai berikut: seorang Ketua merangkap anggota; seorang Wakil Ketua sebagai Ketua Komite Etik merangkap anggota; seorang Kepala Eksekutif Pengawas Perbankan merangkap anggota; seorang Kepala Eksekutif Pengawas Pasar Modal merangkap anggota; seorang Kepala Eksekutif Pengawas Perasuransian, Dana Pensiun, Lembaga Pembiayaan, dan Lembaga J asa Keuangan Lainnya merangkap anggota; seorang Ketua Dewan Audit merangkap anggota; seorang anggota yang membidangi edukasi dan perlindungan Konsumen; seorang anggota exofficio dari Bank Indonesia yang merupakan anggota Dewan Gubernur Bank Indonesia; dan seorang anggota ex-officio dari Kementerian Keuangan yang merupakan pejabat setingkat eselon I Kementerian Keuangan. Kesembilan anggota Dewan Komisioner memiliki hak suara yang sama. Anggota Dewan Komisioner nomor 1 sampai nomor 7 dipilih oleh DPR berdasarkan calon anggota yang diusulkan oleh Presiden. Ketujuh anggota Dewan Komisioner ini memiliki masa jabatan 5 tahun dan dapat diangkat kembali untuk satu kali masa jabatan, sedangkan anggota Dewan Komisioner nomor 8 diangkat dan ditetapkan Presiden berdasarkan usulan Gubernur Bank Indonesia dan anggota Dewan Komisioner nomor 9 diangkat dan ditetapkan Presiden berdasarkan usulan Menteri Keuangan. Kedua anggota Dewan Komisioner ini akan mengakhiri masa jabatannya apabila mereka tidak lagi menjadi anggota Dewan Gubernur BI dan pejabat eselon I di Kementerian Keuangan.

Berbagai larangan dikenakan kepada anggota Dewan Komisioner, yaitu memiliki benturan kepentingan di Lembaga J asa Keuangan yang diawasi oleh OJ K; menjadi pengurus dari organisasi pelaku atau profesi di Lembaga Jasa Keuangan; menjadi pengurus partai politik; dan menduduki jabatan pada lembaga lain, kecuali dalam rangka pelaksanaan fungsi, tugas, dan wewenang 0 J $\mathrm{K}$ dan/atau penugasan berdasar- kan ketentuan peraturan perundang-undangan. Selain itu, antar anggota Dewan Komisioner dilarang mempunyai hubungan keluarga sampai derajat kedua dan semenda. Beralihnya fungsi, tugas dan wewenang Bapepam-LK dan BI ke OJ K, maka para pejabat dan/atau pegawai Bapepam-LK, serta pejabat dan/atau pegawai BI yang melaksanakan fungsi, tugas, dan wewenang pengaturan dan pengawasan di sektor Perbankan, dialihkan untuk dipekerjakan pada OJ $\mathrm{K}$.

OJ $\mathrm{K}$ berwenang melakukan tindakan pencegahan kerugian konsumen dan masyarakat, yang meliputi: memberikan informasi dan edukasi kepada masyarakat atas karakteristik sektor jasa keuangan, layanan, dan produknya; meminta Lembaga J asa Keuangan untuk menghentikan kegiatannya apabila kegiatan tersebut berpotensi merugikan masyarakat; dan tindakan lain yang dianggap perlu sesuai dengan ketentuan peraturan perundang-undangan di sektor jasa keuangan. Selain melakukan tindakan pencegahan, OJ $\mathrm{K}$ juga melakukan pelayanan pengaduan konsumen dan berwenang pula melakukan pembelaan hukum, seperti memerintahkan atau melakukan tindakan tertentu kepada Lembaga Jasa Keuangan untuk menyelesaikan pengaduan Konsumen yang dirugikan Lembaga J asa Keuangan dimaksud dan mengajukan gugatan untuk memperoleh kembali harta kekayaan milik pihak yang dirugikan dari pihak yang menyebabkan kerugian, dan/atau untuk memperoleh ganti kerugian dari pihak yang menyebabkan kerugian pada Konsumen dan/atau lembaga jasa keuangan sebagai akibat dari pelanggaran atas peraturan per-undang-undangan di sektor jasa keuangan.

Forum Koordinasi Stabilitas Sistem Keuangan (FKSSK) dibentuk untuk menjaga stabilitas sistem keuangan, dengan anggota terdiri atas: Menteri Keuangan selaku anggota merangkap koordinator; Gubernur Bank Indonesia selaku anggota; Ketua Dewan Komisioner OJ K selaku anggota; dan Ketua Dewan Komisioner Lembaga Penjamin Simpanan selaku anggota. Pengambilan keputusan dalam rapat FKSSK berdasarkan musyawarah untuk mufakat. Musyawarah untuk mufakat apabila tidak tercapai, maka 
pengambilan keputusan di-lakukan berdasarkan suara terbanyak.

Tugas FKSSK dalam kondisi normal adalah melakukan pemantauan dan evaluasi stabilitas sistem keuangan, melakukan rapat paling sedikit satu kali dalam 3 bulan, membuat rekomendasi kepada setiap anggota untuk melakukan tindakan dan/atau membuat kebijakan dalam rangka memelihara stabilitas sistem keuangan, dan melakukan pertukaran informasi.

FKSSK, dalam kondisi tidak normal menetapkan dan melaksanakan kebijakan yang diperlukan dalam rangka pencegahan dan penanganan krisis pada sistem keuangan sesuai dengan kewenangan masing-masing. Keputusan FKSSK yang terkait dengan penyelesaian dan penanganan suatu bank gagal yang ditengarai berdampak sistemik mengikat Lembaga Penjamin Simpanan. Dalam hal kebijakan FKSSK berkaitan dengan keuangan negara, maka kebijakan tersebut harus diajukan ke DPR untuk mendapat persetujuan. DPR wajib menetapkan keputusan mengenai disetujui atau tidaknya kebijakan tersebut dalam waktu paling lama 24 jam sejak pengajuan persetujuan tersebut diterima oleh DPR.

\section{Perbandingan dengan Negara Lain}

Terdapat beberapa negara yang memiliki lem-baga semacam OJ $\mathrm{K}$ yang berfungsi mengatur dan mengawasi seluruh sektor jasa keuangan di negara tersebut. Sebagian besar lembaga tersebut berhasil dalam menjalankan tugasnya dan hanya sebagian kecil yang gagal. Tulisan ini akan memaparkan satu contoh OJ $\mathrm{K}$ yang gagal dan satu contoh OJ $\mathrm{K}$ yang berhasil. The Financial Services Authority di Inggris adalah salah satu OJ $\mathrm{K}$ yang gagal dan the Financial Services Agency di Jepang adalah salah satu OJ $K$ yang berhasil.

The Financial Services Authority (FSA) adalah otoritas tunggal di Inggris yang bertanggung jawab langsung dalam pengaturan industri jasa keuangan yang mencakup perbankan, asuransi, investasi dan pasar modal. ${ }^{3}$ FSA dibentuk

Heidi Mandanis Schooner, "Central Banks' Role in Bank Supervision in the United States and United Kingdom", Brooklyn International Law J ournal, Year 2003 hlm. 1. pada tanggal 28 Oktober 1997, lembaga ini mengambil alih kewenangan dan tanggung jawab dari 10 badan pendahulunya, termasuk the Personal Investment Authority, Securities and Futures Authority, dan Investment Management Regulatory Organisation. ${ }^{4}$

FSA merupakan lembaga independen di luar pemerintah yang dibiayai oleh pungutan dan denda dari sektor industri jasa keuangan. ${ }^{5}$ FSA dipimpin oleh suatu Dewan (Board) yang ditunjuk oleh Menteri Keuangan. Dewan tersebut terdiri dari seorang Ketua, seorang Deputi, seorang Kepala Pegawai Eksekutif, seorang Kepala Pegawai Operasional, 2 Direktur Pelaksana, dan 9 Direktur Non-Eksekutif yang salah satunya adalah Deputi Gubernur Bank of England (bank sentral) bidang Stabilitas Keuangan sebagai anggota Dewan ex-officio. ${ }^{6}$ FSA memiliki 4 tujuan sebagaimana yang ditentukan oleh the Financial Services Act 2010, yaitu: pertama, menjaga kepercayaan di sistem keuangan; kedua, berperan dalam perlindungan dan peningkatan stabilitas sistem keuangan di Inggris; ketiga, menjamin tingkat perlindungan konsumen yang tepat; dan keempat, mengurangi tingkat kemung-kinan digunakannya suatu bisnis yang dijalankan oleh pihak yang diatur undang-undang untuk tujuan yang berkaitan dengan kejahatan keuangan. ${ }^{7}$

Pada saat krisis keuangan melanda Inggris tahun 2007-2009 yang ditandai dengan ambruknya bank Northern Rock, para pengamat menilai FSA terlalu lemah dan kurang tanggap dengan mengizinkan bank-bank yang tidak bertanggung jawab mempercepat terjadinya credit buble atau menggelembungnya kredit di sektor properti. Sejak abad ke-19 bank-bank di Inggris telah memberikan subprime mortgage, yaitu hipotik yang diserahkan debitur kepada kreditur sebagai jaminan atas utangnya yang kemudian diagunkan kembali oleh kreditur ke bank

\footnotetext{
Financial Services Authority, "About Us", tersedia di website http://www.fsa.gov.uk/about/ who, diakses tanggal 12 Desember 2011.

5 Niamh Moloney, "Regulation of the Market and Intermediaries: Global Comparison and Contrast - What Is Best Practice?", Maquarie J ournal Business Law, Vol 5, year 2008, hlm. 4.

6 Financial Services Authority, Ioc. cit.

7 Ibid.
} 
untuk mendapatkan pinjaman. ${ }^{8}$ Eksistensi subprime mortgage, mengakibatkan banyak orang dengan mudahnya mendapatkan kredit perumahan dari bank. Pada tahun 2000an, subprime mortgage mengalami booming, sehingga industri properti meningkat pesat dan terjadilah credit buble. ${ }^{9}$

Saat itu, credit buble juga melanda Amerika Serikat (AS). Bank-bank di AS bahkan melakukan securitisation, ${ }^{10}$ yakni menjual subprime mortgage ke perusahaan efek dan selanjutnya perusahaan tersebut menerbitkan bond atau obligasi yang dijual di bursa efek. ${ }^{11}$ Bond dari subprime mortgage ini mendapat rating yang tinggi dari para pemeringkat efek, sehingga para investor di bursa efek pun memburu bond tersebut. ${ }^{12}$

Meningkatnya industri properti menyebabkan harga properti melambung tinggi melebihi nilai riilnya. ${ }^{13}$ Pada saat harga sudah sangat tinggi, maka orang tak sanggup lagi membelinya. ${ }^{14}$ Padahal para pemilik properti tak sanggup lagi membayar cicilan kreditnya, karena bank menaikkan suku bunga kredit. ${ }^{15}$ Gelembung kredit pun pecah. Harga properti menurun tajam, sehingga nilai agunan properti di bank tak lagi sesuai dengan jumlah kreditnya dan

8 Christopher Lewis Peterson, "Predatory Structured Finance", Cardozo Law Review, Vol. 28, No. 5, Year 2007, hlm. 2191-2194.

9 David J. Reiss, "Subprime Standardization: How Rating Agencies Allow Predatory Lending to Flourish in the Secondary Mortgage Market", Florida State University Law Review, Vol. 33, Year 2006, hlm. 996-997.

10 Erik F. Gerding, "Code, Crash, and Open Source: The Outsourcing of Financial Regulation to Risk Models and the Global Financial Crisis", Washington Law Review, Vol. 84, No. 2, Year 2009, hlm. 127, 147

11 Steven L. Schwarcz, 2008, "Markets, Systemic Risk, and the Subprime Mortgage Crisis", Southern Methodist University Law Review, Vol. 61, No. 2, hlm. 209-210.

12 Steven L. Schwarcz, 2008, "Disclosure's Failure in the Subprime Mortgage Crisis", Utah Law Review, hlm. 1110.

13 Todd J. Zywicki, dan Joseph Adamson, "The Law \& Economics of Subprime Lending", University of Colorado Law Review, Vol. 80, No. 1, Winter 2009, hlm. 20-21.

14 Christopher Lewis Peterson, "Foreclosure, Subprime Mortgage Lending, and the Mortgage Electronic Registration System", University of Cincinnati Law Review, Vol. 78, No. 4, Year 2010, hlm. 1360.

15 Brent T. White, "Underwater and Not Walking Away: Shame, Fear and the Social Management of the Housing Crisis", Wake Forest Law Review, Vol. 45, Year 2010, hlm. 974. harga bond di bursa efek juga jatuh. ${ }^{16}$ Sebagai tindak lanjut, perbankan mulai mengetatkan pemberian kredit. Akibatnya pertumbuhan ekonomi melambat. Krisis keuangan pun melanda AS. $^{17}$

Krisis di AS tersebut berdampak global, termasuk di Inggris. ${ }^{18}$ Para nasabah berbondong-bondong menarik simpanannya di bank setelah mendengar adanya krisis subprime mortgage di AS. Northern Rock yang mengalami kesulitan likuiditas harus mengajukan loan ke Bank of England dan akhirnya collapse. Industri properti menurun tajam yang menyebabkan pengangguran meningkat. Perbankan juga mulai mengetatkan pemberian kredit, sehingga pertumbuhan ekonomi melambat. Inggris pun diterpa krisis keuangan.

FSA dinilai lambat dalam mengantisipasi menjalarnya krisis keuangan di AS ke Inggris. Dalam kasus ambruknya Northern Rock, FSA mengakui bahwa tindakannya kurang memadai dalam menangani runtuhnya kepercayaan nasabah terhadap bank tersebut. Untuk mencegah situasi semacam ini terjadi lagi, FSA dilaporkan mempertimbangkan untuk mengizinkan suatu bank untuk menunda mengungkapkan ke publik jika ia mengalami krisis keuangan. FSA juga mengabaikan tanda bahaya dari Northern Rock dan tetap mengizinkan bank tersebut untuk beroperasi tanpa suatu program penanggulangan risiko selama beberapa bulan sebelum bank tersebut collapse. Pada tanggal 16 J uni 2010, Pemerintah Inggris mengumumkan rencana untuk membubarkan FSA dan membagi tanggung jawabnya kepada beberapa lembaga baru dan Bank of England. Transisi diperkirakan akan selesai pada 2012. ${ }^{19}$

Di J epang, The Financial Services Agency (FSA) adalah suatu badan pemerintah Jepang

16 Steven L. Schwarcz, “Keynote Address: Understanding the Subprime Financial Crisis", South Carolina Law Review, Vol. 60, No. 3, Year 2009, hlm. 553.

17 Arthur E. Wilmarth, "The Dark Side of Universal Banking: Financial Conglomerates and the Origins of the Subprime Financial Crisis", Connecticut Law Review, Vol. 41, No. 4, Year 2009, hlm. 966-967.

18 Houman B. Shadab, "The Law and Economics of Hedge Funds: Financial Innovation and Investor Protection", Berkeley Business Law J ournal, Vol. 6, Year 2009, hlm. 243-244.

19 lbid. 
yang bertanggung jawab terhadap pengaturan dan pengawasan sektor jasa keuangan, seperti bank, asuransi, surat berharga dan pasar modal. FSA didirikan pada Juli 2000 dan merupakan hasil reorganisasi dari the Financial Supervisory Agency yang didirikan pada Juni 1998. The Financial Supervisory Agency adalah suatu badan administratif yang berfungsi memeriksa dan mengawasi lembaga-lembaga keuangan privat dan mengawasi pasar modal. Setelah reorganisasi, FSA mengambil alih tanggung jawab Menteri Keuangan dalam perencanaan sistem keuangan. ${ }^{20}$

FSA pada awal berdirinya berada di bawah the Financial Reconstruction Commission (FRC) yang merupakan salah satu organ eksternal dari Kantor Perdana Menteri. Sejak J anuari 2001, FSA menjadi organ eksternal dari Kantor Kabinet dan dengan dibubarkannya FRC, maka FSA mengambil alih urusan yang berkaitan dengan penanganan lembaga keuangan yang gagal. FSA dipimpin oleh para Komisioner yang membawahi Hakim Hukum Administrasi, Biro Perencanaan dan Koordinasi, Biro Pemeriksaan, dan Biro Pengawas-an. ${ }^{21}$ Peran dari FSA adalah untuk memastikan stabilitas sistem keuangan Jepang; melindungi nasabah, pemegang polis asuransi, dan investor pasar modal; memeriksa dan mengawasi lembaga-lembaga keuangan dari sektor privat; dan mengawasi transaksitransaksi di pasar modal. ${ }^{22}$

Pada akhir tahun 1990-an dan awal tahun 2000-an, Jepang dilanda krisis ekonomi. Pada masa itu, aset-aset perbankan menga-lami penurunan nilai, padahal rumah tangga di J epang pada umumnya menempatkan separuh dari aset mereka di sektor perbankan. Penurunan nilai aset-aset perbankan tentu saja menjadi beban perekonomian J epang. ${ }^{23}$

Keadaan tersebut diperburuk dengan adanya deflasi yang menyebabkan adanya spe-

20 Financial Services Agency, "Pamphlet", hlm. 2, tersedia di website http://www.fsa.go.jp/en/about/pamphlet. pdf, diakses tanggal $12 \mathrm{~J}$ anuari 2012.

21 lbid.

22 Ibid.

23 Nobusuke Tamaki, Maret 2008, "Bank Regulation in J apan", CESifo DICE Report, hlm. 1, tersedia di website http:/ / www. cesifo-group. de/ portal/ pls/ portal/ docs/ 1/ 1193072. PDF, diakses tanggal 15 J anuari 2012. kulasi yang agresif di bursa efek dan industri properti. Pada masa itu harga-harga efek, tanah dan properti meningkat pesat, sehingga memberikan keuntungan yang tinggi pada investor dan spekulator. Nilai properti sebagai agunan atas kredit perbankan juga menguat, dan bank menempatkan properti sebagai agunan yang tak diragukan lagi tingkat keamanannya ${ }^{24}$ sehingga terjadi asset price bubble atau menggelembungnya harga-harga aset melebihi nilai riilnya. Pada saat harga properti sudah sangat tinggi, maka orang tak sanggup lagi membelinya. Gelembung harga aset pun pecah. Harga ekuitas dan properti menurun tajam. Nilai properti sebagai agunan yang semula tinggi menjadi rendah. Akibatnya, nilai agunan tidak lagi sebanding dengan jumlah kreditnya. Bertambahnya kredit macet menjadi tidak terhindarkan lagi. Perbankan dan bursa efek mengalami krisis, dan krisis ini menyebar dengan cepat ke perekonomian secara keseluruhan. ${ }^{25}$

Berbagai langkah penanganan krisis dilakukan oleh Pemerintah J epang, seperti pemberian blanket guarantee selama 5 tahun terhadap semua simpanan dan kewajiban-kewajiban lain dari lembaga-lembaga keuangan. FSA yang bertanggung jawab menjaga stabilitas sistem keuangan, juga turut berperan dalam penanganan krisis tersebut. Misalnya, FSA melakukan serangkaian pemeriksaan khusus terhadap bank-bank besar untuk memper-cepat proses identifikasi aset-aset yang bernilai rendah dan penghapusan aset-aset tersebut. Hasilnya, nilai aset-aset perbankan mengalami peningkatan. J umlah kredit macet yang mencapai puncaknya pada Maret 2000 sebesar 8,4\% dari total kredit di semua bank, turun menjadi 2,5\% pada September 2007. Langkah-langkah penangan krisis yang dilakukan oleh Pemerintah dan FSA dinilai berhasil, sehingga sistem keuangan J epang relatif stabil hingga kini. ${ }^{26}$

24 Dick K. Nanto, 4 Mei 2009, "The Global Financial Crisis: Lessons from Japan's Lost Decade of the 1990s", Congressional Research Service, hlm. 3, tersedia di website

http:// fpc. state.gov/ documents/ organization/ 125542. pdf, diakses tanggal $20 \mathrm{~J}$ anuari 2012.

25 Ibid.

26 Nobusuke Tamaki, op. cit., hlm. 3. 
Pada saat krisis keuangan melanda AS pada tahun 2007-2010 yang berdampak global, FSA mampu tetap menjaga stabilitas sistem keuangan J epang. Hal ini juga karena lembaga keuangan di Jepang tidak terlalu banyak terlibat dalam subprime mortgage dan gelembung kredit lainnya. FSA, meskipun mengakui bahwa kerugian pada subprime mortgage dari produkproduk lembaga-lembaga keuangan di Jepang tidaklah sedikit, akan tetapi FSA menjamin bahwa kehancuran sistemik pada sistem keuangan J epang tidak akan terj adi. ${ }^{27}$

FSA juga melakukan beberapa tindakan strategis untuk menjaga stabilitas sistem keuangan J epang. Resolusi untuk bank-bank gagal dan pemeriksaan khusus untuk mengidentifikasi aset-aset yang bernilai rendah menjadi perhatian utama FSA. Di samping itu, komunikasi antara FSA dengan lembaga-lembaga keuangan yang diaturnya dilakukan terus menerus, sehingga FSA selalu well informed terhadap perkembangan terakhir lembaga-lembaga tersebut. ${ }^{28}$

Sebelum terbentuknya FSA, kebijakan sektor jasa keuangan yang dilakukan oleh Menteri Keuangan dinilai tidak transparan, tidak dapat diprediksi dan terlalu dekat dengan industri. Oleh karena itu, sejak awal FSA berupaya untuk transparan, menjaga jarak yang cukup dengan industri, bekerja sesuai dengan aturan yang tertulis dari pada kebiasaan tak tertulis dan menjelaskan kriteria yang digunakan dalam tindakan-tindakannya sehingga hasil dari tindakan-tindakan tersebut lebih dapat diprediksi. ${ }^{29}$

\section{Perbandingan OJ K dengan BI dan Bapepam-LK}

Fungsi yang diemban OJ $\mathrm{K}$ bukanlah fungsi yang ringan atau mudah. Berkaca dari pengalaman negara lain, lembaga semacam OJ $\mathrm{K}$ tidak selalu berhasil dalam menjalankan fungsinya. Saat ini OJ K belum bekerja dan sejarah nanti yang akan mencatat berhasil tidaknya OJ K dalam menjalankan fungsinya dan apakah OJ K mampu berfungsi lebih baik dari BI dan

Ibid., hlm. 2 .
lbid.
Ibid., hlm. 3.
Bapepam-LK. Tolok ukur yang dapat digunakan untuk menilai keberhasilan OJ K adalah kemampuannya dalam mencegah dan menangani krisis, independensinya dan kemampuannya dalam memberikan perlindungan kepada konsumen di sektor jasa keuangan.

Pembentukan OJ $\mathrm{K}$ dilatarbelakangi adanya krisis moneter yang melanda Indonesia di akhir tahun 1990an. Krisis tersebut mengakibatkan dilikuidasinya 16 bank dan dikucurkannya Bantuan Likuiditas Bank Indonesia (BLBI) pada sejumlah bank. Lemahnya pengawasan perbankan oleh $\mathrm{BI}$ menyebabkan jatuhnya industri perbankan dan terpuruknya perekonomian Indonesia yang berkepanj angan.

Selain pengawasan yang lemah, BI diduga terlibat praktek kolusi dengan bank-bank yang diawasinya. ${ }^{30}$ Pengucuran BLBI yang merugikan negara diduga karena adanya praktek kolusi antara pejabat BI dengan pemilik bank yang menerima BLBI. Begitu pula dalam kasus bail out Bank Century tahun 2008 diduga karena ada praktek kolusi antara pejabat BI dengan pemilik bank dan pemerintah yang berkuasa pada masa itu, sehingga dialihkannya fungsi pengawasan perbankan dari BI ke OJ K diharapkan dapat mencegah terjadinya praktik serupa di masa datang

Beralihnya fungsi pengawasan perbankan dari BI ke OJ K juga diikuti dengan perpindahan pejabat dan pegawai $\mathrm{BI}$ yang melaksanakan fungsi, tugas dan wewenang pengaturan dan pengawasan sektor perbankan ke OJ K. Pejabat dan pegawai OJ K akan melaksanakan fungsi, tugas dan wewenang yang sama seperti ketika mereka bekerja di BI. Berangkat dari hal ini, maka sulit untuk mengharapkan bahwa oJ $\mathrm{K}$ akan lebih baik dari BI dalam menjalankan fungsi pengawasan perbankan, karena yang terjadi di sini bukanlah perubahan sistem, namun perpindahan kantor aparat pengawas perbankan dari $\mathrm{BI}$ ke OJ K. Artinya, tetap terbuka kemungkinan adanya praktek kolusi di dalam OJ K

\footnotetext{
30 Agus Budianto, “Mengkaji Kejahatan Korporasi di Bidang Perbankan Dalam Sistem Perbankan Indonesia", UPH Law Review, Vol. XI, No. 2, November $2011 \mathrm{hlm}$. 247, 250.
} 
antara aparat yang mengawasi perbankan dengan bank yang diawasinya.

Sebelum pembentukan OJ $\mathrm{K}$, dalam rangka pencegahan dan penangan krisis keuangan dibentuk Komite Stabilitas Sistem Keuangan (KSSK) yang terdiri dari Menteri Keuangan sebagai ketua merangkap anggota dan Gubernur BI sebagai anggota. Dengan dibentuknya OJ K, dalam rangka pencegahan dan penangan krisis dibentuk pula Forum Koordinasi Stabilitas Sistem Keuangan (FKSSK) dengan anggota terdiri atas: Menteri Keuangan selaku anggota merangkap koordinator, Gubernur Bank Indonesia selaku anggota, Ketua Dewan Komisioner OJ K selaku anggota, dan Ketua Dewan Komisioner Lembaga Penjamin Simpanan selaku anggota.

Tidak terdapat perubahan yang mendasar dari KSSK menjadi FKSSK, kecuali jika kebijakan FKSSK menyangkut keuangan negara, maka kebijakan tersebut harus dilaporkan ke DPR untuk mendapat persetujuan. Perubahan ini lebih bersifat politis karena DPR adalah lembaga politik dan karena perubahan ini bertujuan agar kasus seperti bail out Bank Century yang kental dengan nuansa politis tidak akan terjadi lagi. Tidak terdapat perubahan substansial dalam mekanisme pencegahan dan penangan krisis, sehingga sulit untuk mengharapkan OJ $\mathrm{K}$ akan lebih baik dari BI dalam melakukan pencegahan dan penanganan krisis.

Independensi OJ K dari pihak pemerintah maupun non-pemerintah mutlak diperlukan. Namun, dalam susunan Dewan Komisioner OJ K terdapat 2 orang anggota yang berasal dari $\mathrm{BI}$ dan Kementerian Keuangan. Hal ini tentu saja menimbulkan keraguan dapat tidaknya OJ K bebas dari campur tangan Pemerintah. Pada sisi lain, Pemerintah berpendapat, keberadaan 2 pejabat tersebut dalam OJ $\mathrm{K}$ diperlukan untuk menjamin koordinasi, kerjasama, dan harmonisasi kebijakan moneter, fiskal, dan sektor jasa keuangan.

Berkaca dari kegagalan FSA di Inggris di mana salah satu penyebabnya adalah kurangnya komunikasi antara FSA dengan bank sentral dan Menteri Keuangan, maka koordinasi antara OJ K dengan $\mathrm{BI}$ dan Menteri Keuangan memang diperlukan. Namun, bukankah hal ini telah diakomodasi dengan dibentuknya FKSSK yang wajib mengadakan rapat minimal sekali dalam 3 bulan. Dengan demikian, keberadaan 2 pejabat dari BI dan Kementerian Keuangan di dalam Dewan Komisioner OJ K sebenarnya tidaklah mendesak.

Keraguan juga muncul terhadap independensi 7 anggota Dewan Komisioner OJ K lainnya, terutama apabila mereka adalah orang-orang yang lama berkarir di suatu lembaga keuangan swasta. Dikhawatirkan Komisioner tersebut memiliki ikatan emosional dengan lembaga tempat mereka berkarir sebelumnya, sehingga akan mempengaruhi keputusan yang diambilnya. Hal semacam ini pernah terjadi di AS saat terjadinya krisis keuangan tahun 2008. Pada masa itu, beberapa anggota lembaga pengawas perbankan AS yang pernah berkarir di Goldman Sach mendorong Pemerintah untuk menyelamatkan Goldman Sach dengan memberinya suntikan modal ketika bank tersebut collapse. Berkaca dari pengalaman di AS tersebut, maka tidak tertutup kemungkinan akan adanya conflict of interests pada Dewan Komisioner OJ K nantinya.

Namun sebaliknya, apabila 7 Komisioner seluruhnya berasal dari lembaga pemerintahan, keraguan akan independensi OJ $\mathrm{K}$ juga muncul. Oleh karena itu, ketika Pemerintah mengajukan 14 calon anggota Dewan Komisioner OJ K untuk menjalani fit and proper test di DPR, banyak kalangan langsung meragukan independensi OJ K karena ke-14 calon tersebut berasal dari 3 lembaga saja, yaitu $\mathrm{Bl}$, Kementerian Keuangan dan Bank Mandiri. Sebagian calon masih menduduki jabatan di lembaga-lembaga tersebut dan sebagian yang lain berstatus mantan pejabat di lembaga-lembaga tersebut. Dewan Komisioner OJ $\mathrm{K}$ apabila hanya diisi oleh pejabat atau mantan pejabat dari 3 lembaga tersebut, maka menjadi tidak ada gunanya melepaskan fungsi pengaturan dan pengawasan sektor jasa keuangan dari BI dan Kementerian Keuangan untuk diserahkan kepada OJ K. Terpilihnya calon anggota Dewan Komisioner OJ $\mathrm{K}$ yang hanya berasal dari 3 lembaga tersebut menunjukkan, pembentukan OJ $\mathrm{K}$ tidak lebih dari perpindahan kantor sema-ta. Selain itu, 7 Komisio- 
ner tersebut dipilih oleh DPR dengan mekanisme yang sama dengan pemilihan Gubernur BI dan para Deputinya, yaitu diusulkan oleh Pemerintah, diajukan ke DPR untuk menjalani fit and proper test dan kemudian dipilih oleh DPR. Dilihat dari mekanisme ini, maka cukup sulit untuk memastikan bahwa OJ $\mathrm{K}$ akan lebih independen dibandingkan dengan $\mathrm{BI}$ dan BapepamLK.

Berkaitan dengan perlindungan konsumen, selama ini konsumen di sektor jasa keuangan kurang mendapat perlindungan dari $\mathrm{BI}$ dan Bapepam-LK, padahal dewasa ini banyak bermunculan produk-produk dan layanan jasa keuangan yang canggih dan mutakhir, yang berpotensi merugikan konsumen. Selain, telah banyak pula konsumen yang menjadi korban penipuan dari investasi berisiko tinggi yang ditawarkan oleh lembaga-lembaga keuangan. ${ }^{31}$

Lemahnya pengawasan $\mathrm{Bl}$ terhadap perbankan menjadi penyebab munculnya kasus-kasus kejahatan perbankan, seperti penggelapan dana nasabah prioritas Citibank oleh senior relationship managernya, konspirasi kecurangan deposito milik PT Elnusa antara Direktur Keuangan PT Elnusa dengan Kepala Cabang Bank Mega J ababeka ${ }^{32}$ dan tewasnya nasabah kartu kredit Citibank oleh debt collector yang disewa Citibank. ${ }^{33}$ Dalam kasus-kasus tersebut Bl kurang memberikan perlindungan kepada para konsumen yang menjadi korban. Lemahnya pengawasan Bapepam-LK terhadap perusahaan sekuritas dan perusahaan asuransi juga menyebabkan munculnya kasus penggelapan dana nasabah Sekuritas Antaboga dan kasus asuransi Bakrie Life yang gagal membayar nasabahnya. Sejauh ini Bapepam-LK juga tidak dapat memberikan perlindungan yang memadai kepada para konsumen yang menjadi korban dalam kasus-kasus tersebut.

Berkaitan dengan perlindungan terhadap konsumen, dengan terbentuknya OJ K, diharap-

31 Zulkarnain Sitompul, "Memberantas Kejahatan Perbankan: Tantangan Pengawasan Bank", J urnal Hukum Bisnis, Vol. 24 No. 1, Tahun 2005, hlm. 3-6.

32 Agus Budianto, op. cit., hlm. 263-264.

33 J onker Sihombing, "Aspek Hukum Kartu Kredit dan Dilema Penagihannya", UPH Law Review, Vol. XI, No. 2, November 2011, hlm. 209. kan dapat lebih baik. Dalam Dewan Komisioner OJ $\mathrm{K}$ terdapat salah satu Komisioner yang bertanggung jawab terhadap edukasi dan perlindungan konsumen. OJ $\mathrm{K}$ juga mendapat kewenangan untuk melakukan tindakan pencegahan kerugian konsumen dan masyarakat, melakukan pelayanan pengaduan konsumen, dan melakukan pembelaan hukum terhadap konsumen. Dengan demikian diharapkan OJ K akan dapat memberikan perlindungan konsumen le-bih baik dibandingkan dengan BI dan Bapepam-LK.

\section{Penutup \\ Simpulan}

UU No. 21 Tahun 2011 memberikan kewenangan yang sangat besar kepada OJ $\mathrm{K}$ dalam pengaturan dan pengawasan sektor jasa keuangan, di mana kewenangan tersebut selama ini dijalankan oleh dua lembaga berbeda, yaitu $\mathrm{BI}$ dan Bapepam-LK. OJ K yang dipimpin oleh Dewan Komisioner yang terdiri dari 9 orang anggota berwenang untuk melakukan pengawasan, pemeriksaan, penyidikan, perlindungan Konsumen, dan tindakan lain di sektor Perbankan, sektor Pasar Modal, serta sektor Perasuransian, Dana Pensiun, Lembaga Pembiayaan, dan Lembaga J asa Keuangan lainnya.

The Financial Services Authority (FSA) di Inggris adalah salah satu OJ K yang gagal melaksanakan tugasnya dalam mencegah dan menangani krisis keuangan di Inggris, sehingga akhirnya dibubarkan pada tahun 2010. Sementara itu, the Financial Services Agency (FSA) di J epang adalah salah satu OJ $K$ yang berhasil dalam menjaga stabilitas sistem keuangan di J epang. Pada saat krisis keuangan melanda Jepang, FSA menerapkan berbagai langkah strategis, sehingga perekonomian J epang dapat diselamatkan.

Beralihnya fungsi pengaturan dan pengawasan sektor jasa keuangan dari BI dan Bapepam-LK ke OJ K, secara konseptual tidak serta merta membawa perubahan yang lebih baik. Dalam hal pencegahan dan penanganan krisis keuangan, OJ $\mathrm{K}$ diragukan dapat berfungsi lebih baik dari $\mathrm{BI}$, karena tidak ada perubahan sistem yang mendasar, yang ada hanyalah perpindahan kantor aparat pengawas perbankan dari 
$\mathrm{BI}$ ke OJ K. Independensi OJ K juga patut diragukan karena OJ $\mathrm{K}$ memiliki potensi tidak bebas dari campur tangan pihak pemerintah maupun pihak di luar pemerintah. Namun, OJ K diharapkan mampu memberikan perlindungan yang lebih baik kepada konsumen sektor jasa keuangan dibandingkan dengan BI dan Bape-pam-LK.

\section{Saran}

Pembentukan OJ K membutuhkan biaya yang sangat besar, oleh karena itu, sangatlah tidak diinginkan jika OJ $\mathrm{K}$ tidak dapat menjalankan fungsinya dengan baik. Kegagalan FSA di Inggris seyogyanya tidak terjadi pada OJ K. Keberhasilan FSA di Jepang dan lembaga sejenis OJ $K$ di negara-negara lain dapat dijadikan contoh oleh OJ K, agar OJ K berhasil dalam melaksanakan fungsinya. Oleh karena itu, kualitas dan integritas yang tinggi dari anggota Dewan Komisioner OJ $\mathrm{K}$ dan para pegawai OJ K mutlak diperlukan.

\section{Daftar Pustaka}

Budianto, Agus. "Mengkaji Kejahatan Korpora-si di Bidang Perbankan dalam Sistem Perbankan Indonesia". UPH Law Review, Vol. XI. No. 2, November 2011. J akarta: Fakultas Hukum Universitas Pelita Harapan

Financial Services Authority. "About Us", tersedia di website http://www.fsa.gov. uk/about/ who. diakses tanggal 12 Desember 2011;

Financial Services Agency, "Pamphlet", tersedia di website http://www.fsa.go.jp/ en/ about/ pamphlet.pdf, diakses tanggal 12 J anuari 2012;

Gerding, Erik F. "Code, Crash, and Open Source: The Outsourcing of Financial Regulation to Risk Models and the Global Financial Crisis". Washington Law Review. Vol. 84. No. 2, Year 2009. Washington DC: University of Washington-School of Law;

Moloney, Niamh. "Regulation of the Market and Intermediaries: Global Comparison and Contrast-What Is Best Practice?". Maquarie Journal Business Law. Vol 5. Year 2008. Sydney: Faculty of Business and Economics;

Mustaqim, Andika Hendra. "Otoritas J asa Keuangan Sebagai Solusi Sistem Ekonomi
Nasional". Perspektif. Vol. 8. No. 1 Tahun 2010. Medan: Fakultas IImu Sosial dan IImu Politik Universitas Medan Area;

Nanto, Dick K. 4 Mei 2009, “The Global Financial Crisis: Lessons from Japan's Lost Decade of the 1990s", Congressional Research Service, tersedia di website http:/ / fpc. state. gov/ documents/ organization/ 125542. pdf, diakses tanggal 20 J anuari 2012;

Peterson, Christopher Lewis. "Predatory Structured Finance". Cardozo Law Review. Vol. 28. No. 5, Year 2007. New York: Cordozo School of Law;

"Foreclosure, Subprime Mortgage Lending, and the Mortgage Electronic Registration System". University of Cincin-nati Law Review. Vol. 78. No. 4. Year 2010. Cincinnati: College of Law;

Reiss, David J. "Subprime Standardization: How Rating Agencies Allow Predatory Lending to Flourish in the Secondary Mortgage Market". Florida State University Law Review. Vol. 33. Year 2006. Florida: Florida State University;

Schooner, Heidi Mandanis. "Central Banks' Role in Bank Supervision in the United States and United Kingdom". Brooklyn International Law Journal. Year 2003. New York: Brooklyn Law School;

Schwarcz, Steven L. "Markets, Systemic Risk, and the Subprime Mortgage Crisis". Southern Methodist University Law Review. Vol. 61. No. 2. Year 2008. New York: Southern Methodist UniversitySchool of Law;

-.-.-.-. "Disclosure's Failure in the Subprime Mortgage Crisis". Utah Law Review. Year 2008. Utah: The University of Utah;

------. "Keynote Address: Understanding the Subprime Financial Crisis", South Carolina Law Review. Vol. 60, No. 3. Year 2009. Columbia: Law School;

Shadab, Houman B. "The Law and Economics of Hedge Funds: Financial Innovation and Investor Protection". Berkeley Busi-ness Law J ournal. Vol. 6. Year 2009. California: University of California, Berkeley School of Law;

Sihombing, J onker. "Aspek Hukum Kartu Kredit dan Dilema Penagihannya", UPH Law Review, Vol. XI, No. 2, November 2011. Jakarta: Fakultas Hukum Univer-sitas Pelita Harapan; 
Sitompul, Zulkarnain. "Menyambut Kehadiran Otoritas Jasa Keuangan". Pilars. 12-18 Januari 2004. No. 2 Tahun VII. Jakarta: Univ. Mpu Tantular;

-----.. “Memberantas Kejahatan Perbankan: Tantangan Pengawasan Bank", Jurnal Hukum Bisnis, Vol. 24 No. 1. Tahun 2005. J akarta: YAYASAN Pengembangan Hukum Bisnis;

Tamaki, Nobusuke. Maret 2008, "Bank Regulation in Japan", CESifo DICE Report. tersedia di website http:// www.cesifogroup. de/ portal/ pls/ portal/ docs/ 1/ 119 3072.PDF, diakses tanggal 15 Januari 2012;

White, Brent T. “Underwater and Not Walking Away: Shame, Fear and the Social Mana- gement of the Housing Crisis". Wake Forest Law Review. Vol. 45. Year 2010. Winston: Wake Forest University School of Law;

Wilmarth, Arthur E. "The Dark Side of Universal Banking: Financial Conglome-rates and the Origins of the Subprime Financial Crisis". Connecticut Law Re-view. Vol. 41. No. 4. Year 2009. Hart-ford: University of Connecticut School of Law;

Zywicki, Todd J. and Joseph Adamson. "The Law \& Economics of Subprime Lending", University of Colorado Law Review. Vol. 80. No. 1. Winter 2009. Colorado: University of Colorado. 